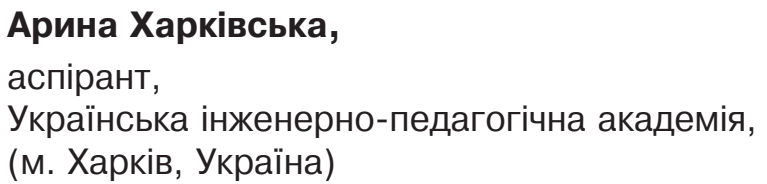

\author{
Aryna Kharkivska, \\ graduate student, \\ Ukrainian engineer-pedagogical academy, \\ (Kharkov, Ukraine) \\ kharkivska21@gmail.com \\ ORCID ID 0000-0003-3411-2847
}

УдК 378.372.035(045)

\title{
МЕТОДОЛОГІЧНІ ПІДХОДИ ДО РОЗВИТКУ КОМУНІКАТИВНОЇ КУЛЬТУРИ МАЙБУТНІХ ВИХОВАТЕЛІВ ЗАКЛАДІВ ДОШКІЛЬНОЇ ОСВІТИ В УМОВАХ МАГІСТРАТУРИ
}

\begin{abstract}
Анотація. На основі аналізу науково-педагогічної та спеціальної літератури у статті обґрунтовано сутність поняття «комунікативна культура майбутнього вихователя закладу дошкільної освіти».

Зосереджено увагу на тому, що для розвитку комунікативної культури майбутніх вихователів закладів дошкільної освіти в умовах магістратури доцільно використовувати наступні методологічні підходи, а саме: дитиноцентристський, системний, андрагогічний, діяльнісний, лінгводидактичний, культурологічний. Доведено, що врахування зазначених підходів сприятиме розвитку комунікативної культури майбутніх вихователів закладів дошкільної освіти в умовах магістратури, а також розвитку у них відповідних компетентностей, набуття необхідних знань, особистісних комунікативних якостей i вмінь із метою формування висококваліфікованого та конкурентоздатного фахівця на міжнародному ринку праці.
\end{abstract}

Ключові слова: комунікативна культура, майбутній вихователь закладу дошкільної освіти, дитиноцентристський підхід, системний підхід, андрагогічний підхід, діяльнісний підхід, лінгводидактичний підхід, культурологічний підхід.

\section{METHODOLOGICAL APPROACHES TO THE DEVELOPMENT OF COMMUNICATIVE CULTURE OF FUTURE EDUCATORS OF PRE-SCHOOL EDUCATION IN THE MAGISTRACY}

\begin{abstract}
Based on the analysis of scientific-pedagogical and special literature, the author substantiates the essence of the concept of "communicative culture of the future preschool teacher". It is proved that for the development of communicative culture of future preschool teachers in the conditions of magistracy it is expedient to use the following methodological approaches. The child-centered approach focuses the educational process on the development of the communicative culture of future preschool educators, which provides the conditions for the development of cognitive interest of students in the world of preschool childhood, motives for pedagogical interaction and understanding with children, valuable human interaction who has certain rights to be recognized by future caregivers; professionals who are able to penetrate the world of feelings and emotions, ready to accept the views of children, showing confidence, respect and tolerance.

Taking into account the systematic approach allows analyzing the process of development of communicative culture of future preschool teachers, but does not provide knowledge on the basis of which principles it is necessary to build the educational process, what content, forms and methods to fill it.

The value of the andragogical approach is that it implies the need to determine the content, forms and methods of development of communicative culture of future educators in the conditions of magistracy, which largely correspond to adult learning, encourage critically to assess the level of their professional knowledge, skills, skills, promote the development of its culture.

Taking into account the activity approach as a theoretical and methodological basis for the study of the development of communicative culture of future preschool educators is determined by the fact that it allows to determine the components of the system of development of communicative culture of future teachers, their procedural regularity, enables such organization of the process of development of communicative education, involves constant communication between teachers and students.

The use of the linguo-didactic approach as a theoretical and methodological basis for the study of the development of communicative culture of future preschool educators directs the study to take into account the system-forming position of language as a general personality trait that determines the spiritual, intellectual, linguistic development of a future educator.

The cultural approach directs the educational process to the development of the communicative culture of future preschool educators, which provides the creation of conditions for the formation and development of communicative personality of future educators, able to build subject-subject relationships, optimally use the means of communication according to age-
\end{abstract}


psychologists and individuals features of the interlocutor, follow the etiquette rules in communication, as well as capable of cultural self-development and successful professional self realization in professional activity.

Keywords: communicative culture, future preschool teacher, child-centered approach, systemic approach, andragogical approach, activity approach, lingvodidactic approach, cultural approach.

\section{ВСТУП}

Постановка проблеми. Проблема розвитку комунікативної культури майбутніх вихователів закладів дошкільної освіти, як однієї з якостей розвиненої особистості, необхідної для майбутньої інноваційної, освітньої, виховної, розвивальної, комунікативної, управлінської, моніторингової, адміністративної, фінансовоекономічної, соціальної, психологічної діяльності педагога, залишається актуальною на сучасному етапі розвитку суспільства, оскільки ефективність педагогічної взаємодії між суб'єктами освітнього процесу залежить від уміння встановлювати ділові й особистісні відносини, орієнтуватися в різних комунікативних стандартних і нестандартних ситуаціях, визначати оптимальні шляхи подолання комунікативних проблем і розбіжностей, враховувати індивідуальні особливості дітей, їх батьків, педагогічного колективу.

«Проблема освіти виходить на передній план у зв'язку зі становленням нового типу суспільних відносин ..... Наразі в Україні склалася суперечлива ситуація між вимогами суспільства до фахівця, з одного боку, і реальним рівнем його підготовки у вищих навчальних закладах - з іншого» (Харківська А., 2009, с. 411-420).

Отже, комунікативна культура $€$ необхідною складовою професійної підготовки майбутніх вихователів закладів дошкільної освіти, бо недостатній рівень сформованості та розвитку комунікативних якостей, знань, умінь і навичок суттєво знизить їх майбутню професійну придатність. Тому перед закладами вищої педагогічної освіти стоїть завдання створити оптимально сприятливі умови для підвищення рівня комунікативної культури майбутніх фахівців.

Аналіз останніх досліджень і публікацій. Проблему розвитку комунікативної культури майбутніх вихователів закладів дошкільної освіти в умовах магістратури ми розглядаємо в контексті професійної підготовки, теоретичне підґрунтя якої визначено в таких аспектах: загальні питання вдосконалення змісту підготовки майбутніх вихователів дошкільної освіти (Л. Тудор, Л. Артемова, Г. Бєлєнька та інші); особливості підготовки майбутніх вихователів дошкільної освіти в різних країнах (М. Хмелак, Ю. Водопівець Дж. Ейнарсдоттір, А. Хаясі та інші); міжнародні тенденції в підготовці фахівців дошкільної освіти (Ю. Балахович, К. Новак-Фабриковські, С. Зброг); формування ключових компетентностей майбутніх педагогів дошкільної освіти (П. Вілямс, Т. Вуорінен, К. Петровиця, А. Сандберг, С. Шерідан). Натомість, розвиток комунікативної культури майбутніх вихователів закладів дошкільної освіти в умовах магістратури ще не став предметом окремого дослідження.

MЕТА І ЗАВДАННЯ ДОСЛІДЖЕННЯ: обґрунтувати доцільність використання дитиноцентристського, системного, андрагогічного, діяльнісного, лінгводидактичного, культурологічного методологічних підходів до розвитку комунікативної культури майбутніх вихователів закладів дошкільної освіти в умовах магістратури.

\section{МЕТОДИ ДОСЛІДЖЕННЯ}

Для розв'язання поставлених у статті завдань використано системний і порівняльний аналіз: філософської, педагогічної, психологічної, спеціальної літератури, довідкової, навчально-методичної та інструктивнонормативної документації з метою вивчення стану розробки дослідження та з'ясування методологічних підходів до розвитку комунікативної культури майбутніх вихователів закладів дошкільної освіти в умовах магістратури.

\section{РЕЗУЛЬТАТИ ДОСЛІДЖЕННЯ}

Професійна діяльність вихователя пов'язана з необхідністю постійного спілкування з дорослими та дітьми, різними за індивідуально-психологічними характеристиками, готовністю вступати в контакт. Особливості професії вихователя вимагають від педагога високого рівня його комунікативної культури.

Багатоаспектність і багатофункціональність процесу розвитку комунікативної культури майбутніх вихователів закладів дошкільної освіти в умовах магістратури потребує дослідження на підставі комплексу підходів, що доповнюють один одного. У зв'язку з цим здійснення цілісного аналізу процесу розвитку комунікативної культури стає можливим у разі використання сукупності методологічних підходів: дитиноцентристського, системного, андрагогічного, діяльнісного, лінгводидактичного та культурологічного.

В. Кремінь стверджує: «Є необхідність якомога більше наблизити навчання і виховання кожної дитини до ії сутності, конкретних здібностей, майбутньої життєвої траєкторії людини. Це явище я називаю дитиноцентризмом в освіті» (Кремень В., 2009, с. 1-6.)

Погоджуючись із І. Луценко, наголошуємо, що дитиноцентристський підхід спрямовує вихователів на встановлення суб'єкт-суб'єктних відносин із дітьми дошкільного віку, взаємодію з ними як з рівноправними учасниками освітнього процесу, що передусім проявляється в організації комунікативно-мовленнєвої діяльності дошкільників (Луценко І., 2015, с. 5-10).

Отже, дитиноцентристський підхід орієнтує освітній процес на розвиток комунікативної культури майбутніх вихователів закладів дошкільної освіти, що передбачає створення умов для розвитку пізнавального інтересу студентів до світу дошкільного дитинства, мотивів педагогічної взаємодії та взаєморозуміння з дітьми, ціннісного гуманного ставлення до дитини як суб'єкта спілкування та педагогічної взаємодії, який володіє певними правами, що мають бути визнані майбутніми вихователями; фахівців, здатних проникнути у світ почуттів і переживань, готових прийняти погляди дітей, виявляючи довіру, повагу і толерантність. 
Комунікативна культура майбутнього вихователя закладу дошкільної освіти є складною системою, тому аналіз її сутності, структури, компонентів, функціонування та розвитку можливий тільки з позицій системного підходу.

Застосування системного підходу як теоретико-методологічної основи дослідження передбачає необхідність: розглянути процес розвитку комунікативної культури майбутніх вихователів закладів дошкільної освіти як складну педагогічну систему; визначити особливості та структуру цього процесу; виділити структурні компоненти розвитку комунікативної культури майбутніх вихователів закладів дошкільної освіти; теоретично обґрунтувати та експериментально перевірити модель розвитку комунікативної культури майбутніх вихователів закладів дошкільної освіти.

Із позиції системного підходу комунікативну культуру майбутнього вихователя можна визначити як елемент цілісної системи особистісних якостей майбутнього вихователя, системоутворювальним компонентом якої $€$ розвиток комунікативної культури майбутніх вихователів закладів дошкільної освіти в умовах магістратури.

Урахування системного підходу дозволяє проаналізувати процес розвитку комунікативної культури майбутніх вихователів закладів дошкільної освіти, але не передбачає отримання знань про те, на підставі яких саме принципів потрібно будувати освітній процес, яким змістом, формами та методами його наповнити. Тому вивчення зазначеної проблеми необхідно доповнити особистісним контекстом її розгляду з урахуванням андрагогічного підходу.

В «Українському педагогічному словнику» визначено сутність андрагогіки: «Це педагогіка дорослих, одна 3 педагогічних наук, яка займається дослідженням проблем освіти, самоосвіти й виховання дорослих» (Гончаренко С., 1997, с. 375$)$

Отже, значення андрагогічного підходу полягає в тому, що він передбачає необхідність визначити зміст, форми та методи розвитку комунікативної культури майбутніх вихователів в умовах магістратури, які значною мірою відповідають навчанню дорослої людини, спонукають критично оцінити рівень своїх професійних знань, умінь, навичок, сприяють розвитку ї̈ комунікативної культури.

Комунікативна культура майбутнього вихователя може виражатися в його повсякденному житті та професійній діяльності у процесі взаємодії з об'єктами освітнього процесу закладу дошкільної освіти. Тому застосування діяльнісного підходу дозволяє всебічно розглядати розвиток комунікативної культури та здійснювати аналіз цієї культури у процесі професійно-комунікативної діяльності.

О. Бєляк стверджує, що сутність діяльнісного підходу полягає у створенні необхідних умов для стимулювання позитивного потенціалу майбутніх вихователів, відкритості до нових знань, досвіду, постійного розвитку, а найголовніше - отримання задоволення від власного самовдосконалення, праці в закладі дошкільної освіти, розвитку професійних знань і вмінь, професійно значущих особистісних здібностей. Діяльнісний підхід лежить в основі будь-якої діяльності, в тому числі професійно-комунікативної (Бєляк О., 2011, с. 76-81).

Професійно-комунікативна діяльність у галузі дошкільної освіти визначається як багаторівнева система, що має множину характеристик, зокрема: цілісність, структурність, ієрархічність, усвідомленість, предметність, суб'єктність; визначення потреб, мотивів, мети, функцій, засобів і дій, результату.

Урахування діяльнісного підходу як теоретико-методологічної основи дослідження розвитку комунікативної культури майбутніх вихователів закладів дошкільної освіти зумовлено тим, що він дозволяє визначити компоненти системи розвитку комунікативної культури майбутніх педагогів, їх процесуальну закономірність, уможливлює таку організацію процесу розвитку комунікативної культури майбутніх вихователів закладів дошкільної освіти, що передбачає постійну комунікативну взаємодію викладачів і студентів.

Обов'язковим елементом комунікативної культури майбутнього вихователя закладу дошкільної освіти є вільне володіння державною та іноземною мовами. Майбутній педагог у професійній діяльності повинен чітко та лаконічно викладати матеріал, спираючись на великий словниковий запас, володіти логікою та синтаксисом мови, правильно використовувати необхідні стилістичні засоби, розрізняти особливості усного й писемного мовлення, знаходити та реалізовувати адекватні форми викладу матеріалу, включаючи образність, виразність мови, інтонацію, силу необхідного звучання. Лінгвістична наука досить повно описує походження, будову мови, принципи її функціонування в суспільстві. У зв'язку з цим, щоб розвинути комунікативну культуру майбутнього вихователя закладу дошкільної освіти, необхідно звернутися до лінгводидактичного підходу.

А. Богуш і Н. Гавриш визначають лінгводидактику як педагогічну галузь науки, що досліджує закономірності розвитку мовлення особистості; специфіку педагогічної діяльності, спрямовану на формування мовленнєвих навичок особистості; засоби, форми, методи та прийоми навчання рідної або іноземної мови (Богуш А., Гавриш Н., 2015).

Отже, використання лінгводидактичного підходу як теоретико-методологічної основи дослідження розвитку комунікативної культури майбутніх вихователів закладів дошкільної освіти спрямовує дослідження на врахування системоутворювальної позиції мови як загальної властивості особистості, що зумовлює духовний, інтелектуальний, мовний розвиток майбутнього вихователя закладу дошкільної освіти.

Комунікативна культура майбутнього вихователя закладу дошкільної освіти є культурологічним феноменом, тому для його дослідження вважаємо за доцільне звернутися до методології культурологічного підходу.

І. Бех розуміє культурологічний підхід як «цілеспрямований, побудований на наукових засадах процес прилучення особистості до культури, в ході якого здійснюється передача багатовікового людського досвіду (теоретичного, ціннісного, практичного) від покоління до покоління і розвиток його відповідно до сучасних реалій» (Бех І., 2002, C. $143-156)$.

Реалізація культурологічного підходу, з одного боку, сприяє збереженню та розвитку загальної базової культури в цілому, а з іншого - створює сприятливі можливості для розвитку в майбутніх вихователів саме комунікативної 
культури. Застосовуючи культурологічний підхід, можна виявити культурну зумовленість досліджуваного нами явища, сутнісні характеристики комунікативної культури майбутніх вихователів, виділити структуру, визначити зміст, форми, методи та засоби розвитку комунікативної культури.

Отже, культурологічний підхід спрямовує освітній процес на розвиток комунікативної культури майбутніх вихователів закладів дошкільної освіти, що передбачає створення умов для формування та розвитку комунікативної особистості майбутніх вихователів, здатних будувати суб'єкт-суб'єктні взаємини, оптимально використовувати засоби комунікації відповідно до вікових та індивідуально-психологічних особливостей співрозмовника, дотримуватися етикетних правил у спілкуванні, а також здатних до культурного саморозвитку та успішної професійної самореалізації у професійній діяльності.

\section{ВИСНОВКИ ТА ПЕРСПЕКТИВИ ПОДАЛЬШИХ ДОСЛІДЖЕНЬ}

У контексті європейської інтеграції, яка відкриває шлях до активного міжнародного співробітництва у сфері дошкільної освіти, особливого значення набуває розширення міжнародних, професійних контактів із різними категоріями дітей дошкільного віку, батьками дітей, колегами, адміністрацією, партнерами закладу дошкільної освіти, органами управління й самоврядування та формування і розвиток комунікативної культури педагога. Вирішення зазначеної наукової проблеми може бути успішно здійснено, якщо в якості теоретикометодологічного підґрунтя розвитку комунікативної культури майбутніх вихователів закладів дошкільної освіти в умовах магістратури виступить синтез таких підходів: дитиноцентристського, системного, андрагогічного, діяльнісного, лінгводидактичного та культурологічного.

\section{СПИСОК ВИКОРИСТАНИХ ДЖЕРЕЛ}

Бєляк, О. М. (2011). Діяльнісний підхід до розвитку комунікативних якостей мовлення. Науковий вісник Південноукраїнського національного педагогічного університету ім. К. Д. Ушинського, 11-12, 76-81.

Бех, І. Д. (2002). Особистісно-орієнтована модель виховання як науковий конструкт. Психолого-педагогічні проблеми сільської школи: збірник наукових праць, 3,143-156.

Богуш, А. М., Гавриш, Н. В. (2015). Дошкільна лінгводидактика: Теорія і методика навчання дітей рідної мови в дошкільних навчальних закладах: підручник. Вид. 2-ге, доповнене / За ред. А. М. Богуш. Київ: Видавничий Дім «Слово».

Гончаренко, С. У. (1997). Український педагогічний словник. Київ.

Кремень, В. (2009). Про «Дитиноцентризм», або Чому освіта України потребує структурних змін. День: щоденна всеукраїнська газета, 210 (3130), 19 листопада, 1-6. URL: https://day.kyiv.ua/uk/article/cuspilstvo/pro-ditinocentrizm

Луценко, І. (2015). Спілкуємося на рівних. Організація комунікативно-мовленнєвої діяльності дошкільнят на засадах дитиноцентризму. Дошкільне виховання, 1, 5-10.

Харківська, А. А. (2009). Формування інформатичної компетентності майбутнього вчителя-інформатики у педагогічному ВНЗ. Проблеми інженерно-педагогічної освіти: зб. наук. пр. / відп. ред. Брюханова Н. О. Харків: УІПА.

\section{REFERENCES}

Bieliak, O. M. (2011). Diialnisnyi pidkhid do rozvytku komunikatyvnykh yakostei movlennia. Naukovyi visnyk Pivdennoukrainskoho natsionalnoho pedahohichnoho universytetu im. K. D. Ushynskoho, 11-12, 76-81.

Bekh, I. D. (2002). Osobystisno-oriientovana model vykhovannia yak naukovyi konstrukt. Psykholoho-pedahohichni problemy silskoi shkoly: zbirnyk naukovykh prats. Kyiv, 3, 143-156.

Bohush, A. M., Havrysh, N. V. (2015). Doshkilna linhvodydaktyka: Teoriia i metodyka navchannia ditei ridnoi movy v doshkilnykh navchalnykh zakladakh: pidruchnyk. Vyd. 2-he, dopovnene/Za red. A. M. Bohush. Kyiv: Vydavnychyi Dim «Slovo».

Honcharenko, S. U. (1997). Ukrainskyi pedahohichnyi slovnyk. Kyiv.

Kremen, V. (2009). Pro «Dytynotsentryzm», abo Chomu osvita Ukrainy potrebuie strukturnykh zmin. Den: shchodenna vseukrainska hazeta, 210 (3130). 19 lystopada, 1-6. Retreived from: https://day.kyiv.ua/uk/article/cuspilstvo/pro-ditinocentrizm

Lutsenko, I. (2015). Spilkuiemosia na rivnykh. Orhanizatsiia komunikatyvno-movlennievoi diialnosti doshkilniat na zasadakh dytynotsentryzmu. Doshkilne vykhovannia, 1, 5-10.

Kharkivska, A. A. (2009). Formuvannia informatychnoi kompetentnosti maibutnoho vchytelia-informatyky u pedahohichnomu VNZ. Problemy inzhenerno-pedahohichnoi osvity: zb. nauk. pr. / vidp. red. Briukhanova N. O. Kharkiv: UIPA. 